Article

\title{
Music as a Resource Against Bullying and Cyberbullying: Intervention in two Centers in Spain
}

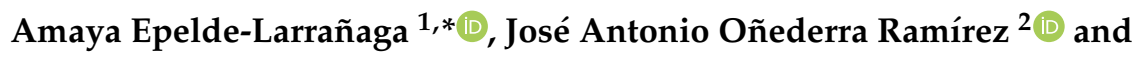 \\ Ligia Isabel Estrada-Vidal ${ }^{3}$ \\ 1 Department of Didactics of Musical, Plastic and Corporal Expression, Faculty of Education and Sports \\ Sciences of Melilla, University of Granada, 52005 Melilla, Spain \\ 2 Department of Euskera-Basque Language, Institute of Secondary Education Bideberri of San Sebastian, \\ 20011 San Sebastian, Spain; joxeano@hotmail.com \\ 3 Department of Research Methods and Diagnosis in Education, Faculty of Education and Sports Sciences of \\ Melilla, University of Granada, 52005 Melilla, Spain; ligia@ugr.es \\ * Correspondence: aepelde@ugr.es; Tel.: +34-61-853-3752
}

Received: 28 January 2020; Accepted: 5 March 2020; Published: 7 March 2020

check for updates

\begin{abstract}
Aggressive conflicts are quite frequent in schools, and all students take part in them. Bullying and cyberbullying are the most common methods used. The main objective of this work was to prevent and reduce aggressive behaviors among school children. In this study we present the results of an intervention that we have carried out in two education centers, one public and one semi-public, with students between the ages of 11 and 14 . This intervention was done using music and was reinforced by a talk about human values. Two hundred adolescents from the autonomous city of Melilla, Spain, took part in this study. This was a quasi-experimental study with pre-test/post-test design and an equivalent randomized control group. The instrument used was the Garaigordóbil Cyberbullying Test. The musical intervention lasted for four months. The effect of the intervention program was checked through the t-test of related samples, checking the size of the effect through Cohen's $\mathrm{d}$. The results showed a decrease in victims, aggressors and witnesses of cyberbullying in the semi-public education center and a decrease in victims of bullying in the public center. It is concluded that music can be a valid resource in making people aware of aggressive behaviors and in helping to reduce it.
\end{abstract}

Keywords: adolescents; aggression; schools; music; students; music therapy

\section{Introduction}

Conflict occurs in all relationships between human beings, and in every social sphere, due to the need for every individual to defend their own interests of survival and well-being. Daily nonviolent conflicts are a reality of life, and they sometimes reach levels so high that they should be considered and called violence. These aggressive conflicts are quite frequent in schools, and unfortunately, most students take part in them, be it as aggressors, victims or bystanders [1]. Bullying and cyberbullying are the most common methods used and include behaviors such as mockery, threats, intimidation, physical aggression and insults [1-4].

Bullying is an aggression or peer violence repeatedly perpetrated with the intention of harming the partners who cannot defend themselves; it is carried out in a visible way between victim and aggressor. However, the use of new technologies has increased the possibilities and mechanisms to further harm victims; cyberbullying is a continuous harassment for the victim who may be attacked anytime and anywhere. 
Adolescence is the stage where such attacks mainly occur; therefore, we selected a sample of adolescents between the ages of 11 and 14. Acts of aggression occur mainly inside schools, and it is in the recreation area and the playground where they occur with the greatest frequency. In relation to this, Serrano and Iborra (in [1]) state that " $75 \%$ of cases of harassment occur in class, $60 \%$ in the playground, $40 \%$ in halls and $10 \%$ around the school centre". Many investigations have reinforced the idea that having friends, being liked and popular, going with the class as a whole, and defending classmates' actions all help to protect against victimization, and that even the presence of a single friend can prevent aggression [2,3].

In addition, there are studies that indicate that students in need of educational support are at greater risk and suffer higher levels of harassment and intimidation than their peers; therefore, they constitute a group at greater risk of vulnerability within the school system [5,6].

Cyberbullying is usually an extension of bullying and both overlap between them [7-9].

Frequently, students who suffer bullying are also victims of cyberbullying, due to the opportunities that new technologies offer aggressors to inflict such damage on the victims.

The causes of aggressive behaviors may be the "weak ties of friendship" between adolescents, as a predisposing factor, and the participation of a third party as the cause of conflict. In addition, the image that many adolescents have of violence "as a game, as a form of fun" causes them to relate incorrectly with their colleagues. In addition, "gender stereotypes" can compound the tendencies for aggression in such way that these relationships between colleagues cannot be considered "egalitarian nor respectful" [10].

The actions of educational centers play an important role in the interaction between the variables that influence the violent processes and, therefore, should be at the heart of every plan of prevention.

The incidence of bullying and cyberbullying in Spain has been confirmed for years in a number of studies. Unfortunately, all of them provide data in which verbal aggression and social exclusion are the most commonly used methods. More recently the "Save the Children" organization has found that during 2016, "9.3\% of children have suffered bullying and $6.9 \%$ cyberbullying" [5].

Focusing on the two education centers studied, data were obtained before the intervention (pre-test) in 2018 from a sample of 227 adolescents from the autonomous city of Melilla, to assess the incidence of bullying and cyberbullying, with the following results: In relation to bullying, it was found that verbal aggression was by far the most common method, since $37 \%$ of respondents suffered from this. Nevertheless, $14.6 \%$ of victims suffered from physical aggression, $13.7 \%$ complained of experiencing social aggression, and $14.1 \%$ suffered from psychological aggression.

In the case of cyberbullying, $25.1 \%$ of students surveyed claimed to have received offensive and insulting messages via mobile phone or the internet, and $8.8 \%$ received calls of a similar type; $13.7 \%$ received anonymous calls, and $6.6 \%$ have been threatened or blackmailed. Furthermore, $15.4 \%$ experienced the theft of their digital password, and $14.1 \%$ claimed to have been insulted online [11].

In the case of bullying, we see that more women than men have suffered social aggression $(16.9 \%$ vs. $9.8 \%)$. In the case of cyberbullying, women are victims of defamation $(25.8 \%)$ to a much greater extent than men (9.7\%) and receive more anonymous calls than men (19.3\% vs. $14.6 \%)$.

As for bullying, there are more witnesses who claim to have seen physical aggression in semi-public education centers than in public ones ( $46 \%$ vs. $32.3 \%$ ), although both percentages are very high, and the occurrence of physical aggression in the last year of primary education (6th grade) is greater than in the first year of secondary education (7th grade) $(21.6 \%$ vs. $12 \%)$. However, there are more witnesses who claim to have seen social aggression in secondary education than in primary education $(10.2 \%$ vs. $0 \%)$.

With regard to cyberbullying, we observe that victimization is greater in the semi-private education center than in the public one (7.4\% vs. $1.0 \%)$. However, there are more witnesses of cyber aggression in the public education center than in the semi-public one (48.6\% vs. 32\%). As for cyberbullying, it is usually in secondary schools where higher levels of aggression are found, although it depends on the type. On victimization, the results are as follows: receiving offensive and insulting messages via 
mobile or the internet- $37.1 \%$ in secondary vs. $13.3 \%$ in primary-writing defamatory comments and telling lies or secrets about the victim through social networks- $-10.2 \%$ in secondary vs. $0 \%$ in primary. On the other hand, in relation to receiving death threats through mobile or social networks, $10 \%$ of victims are in primary school, while in 7 th grade (first year of secondary education) there are only $0.6 \%$. However, witnesses of cyberbullying, who see the sending of offensive and insulting messages via mobile or social networks, are much more numerous in secondary than in primary education $(44.9 \%$ vs. $25.1 \%)$ [11].

Many investigations have provided evidence on the negative physical and psychological consequences that this type of behavior causes in both victims and aggressors [3,4,12-15].

Loss of self-esteem, increased lack of self-confidence, and post-traumatic stress are very frequent symptoms found in victims of harassment [16]. The highest levels of emotional loneliness and depressive mood in adolescents are found in those who play the roles of passive victims and aggressive victims in situations of school violence [2]. The victims of mockery and social exclusion are the ones that have the most "recurrent suicidal" thoughts [5]. Victims of bullying can in time evolve into bullies themselves within the school environment, and later as adult aggressors in society. The perpetrators of homicides are more likely to have been victims of bullying [17]. Notably, "60\% of students, who between 6th and 9th grade were shown to be aggressors, were arrested at least once before the age of 24" [3].These statements cause us to consider the worrying risks from the increase in the number of aggressors, both in school and adult life.

On the other hand, emotional intelligence is the capacity and ability of people to manage their emotions and to empathize with those of others $[18,19]$. It is a very important aspect to take into consideration in the case of bullying. Students with a high degree of aggressiveness have low scores in emotional intelligence [18,19] and social skills [20]. In relation to this, it is necessary for schools to work towards "emotional education, attention to diversity, and cooperative learning and work" [13]. Many researchers designed programs with elements of social learning theory by using music and music therapy, which led to a decrease in bullying and cyberbullying. The skills to teach are self-regulation, perspective taking, emotion management, problem solving, communication skills and friendship skills. The results have been successful for peer relations and self-management skills. As Shafer and Silverman have shown, intervention programs provided with music will always be more effective and motivating than interventions that do not include music [20]. For this reason, we chose to make an intervention based on music and then reinforce it with talks about human values.

Music is a combination of sounds, organized through certain elements such as rhythm, melody, harmony, texture, form, beats, pulse, accents, tones, speed and phrasing, which come together to create a whole that expresses emotions, ideas and feelings. In a group, music requires one to self-regulate their emotions to achieve a unified version of the musical piece. With music, students learn to manage their emotions and improve standards of respect. Music is a universal tool that is characterized by its capacity for openness and social unification, and through it the development of the whole person is possible, both as an individual and socially. Music serves as a means of problem-solving; through self-regulation, the student learns to manage their emotions (anxiety, frustration, anger), which otherwise could have led to a form of active violence. Musical work within a group improves people's self-esteem, which is a very important factor as it increases the self-esteem of those who have been victims of violence, allowing them to manage the problem in a more positive way. Similarly, self-regulation of emotions among those who have been passive bystanders to instances of violence will help them to be more empathetic towards victims.

Given this, we decided to use music performed by a group because, in this way, the music becomes even more effective, enhancing socialization and bringing people together; respect for others is cultivated and the ability to adapt to the group is developed. "It is necessary to relate individual ideas to the group's vision" [21] and "the social man naturally seeks to share, communicate(...)and if the coordinates of empathy, affectivity and communicability work properly, group production can be highly profitable" because the game is always "play with" [22]. 
In the field of musical education, music and its learning are justified as a means of social cohesion, since it develops a sense of unity and collectivity. Thanks to music, human feelings are able to express themselves more coherently than through other forms of expression. These feelings are shared and can achieve unexpected levels of harmony among individuals. "Musical education has a special emotional effect on children, greater than any other phenomena that may be related to reality... it helps them to express themselves and establish social relationships that reinforce collective work" [23].

The general objective of this intervention is the prevention and reduction of cases of aggressive violence in the educational centers of La Salle and Enrique Nieto in Melilla.

The objectives based on statistical analyses are as follows:

- O1: Describe violent behaviours, bullying and cyberbullying, as well as the roles of the different actors involved, in a sample composed of adolescents from 6th grade (last year of primary education) and the first compulsory year of secondary education (7th grade) in Melilla;

- O2: Analyse the effect of an intervention program, based on music practice reinforced with education in values, on aggressive behaviours, bullying and cyberbullying in adolescents in 6th grade (last year of primary education) and the first compulsory year of secondary education (7th grade).

The hypotheses based on statistical analyses are as follows:

Hypothesis 1 (H1): After the intervention, the public education centre will reflect higher rates of bullying than the semi-private one;

Hypothesis 2 (H2): Adolescents belonging to the different experimental groups will reduce the bullying and cyberbullying, compared to those of the control group, as the result of the intervention program.

\section{Materials and Methods}

We cannot ignore the data that we have presented in a previous section, obtained from the centers under study, and we have considered very seriously the need to carry out an intervention for the prevention and reduction of the problem of bullying and cyberbullying, and the interaction and coexistence among primary and secondary school students.

\subsection{Study Design and Participants}

We adopted a longitudinal, quasi-experimental study with a pre-test/post-test design and an equivalent randomized control group in natural groups-a 'cluster-randomized' controlled trial [24]. For the school year 2017/2018 there were 2536 students enrolled, 1165 in 6th grade (last year of primary education) and 1371 in 7 th grade (first year of secondary education). A representative sample of 227 students was established (sample error of $0.05 ; \mathrm{CI}=90 \%$ ). Nevertheless, during the intervention program, 27 participants were removed, making a final sample of 200 adolescents of the autonomous city of Melilla. The representation by gender was $44 \%(n=88)$ of men and $56 \%(n=112)$ of women, aged between 11 and 14 years (11.98 \pm 0.72$)$. The educational centers participating were IES La Salle (center A; a semi-public school—a privately managed school funded by the state) and Enrique Nieto (center B; a public secondary school), with a distribution of $60.5 \%(n=121)$ and $39.5 \%(n=79)$ of the participants, respectively. For the development of the intervention program, an equivalent control group (CG) and experimental group (EG) were set up in each educational center, based on the fact that they started from different educational, social and cultural bases. The distributions for each group and center are shown in Table 1. 
Table 1. Sample distribution according to education center (public vs. semi-private) and type of group (CG vs. EG).

\begin{tabular}{|c|c|c|c|c|}
\hline & & \multicolumn{2}{|c|}{ Centre } & \multirow{2}{*}{ Total } \\
\hline & & La Salle & Enrique Nieto & \\
\hline \multirow{2}{*}{ Group } & Experimental & $56.3 \%(n=63)$ & $43.8 \%(n=49)$ & $100 \%(n=112)$ \\
\hline & Control & $65.9 \%(n=58)$ & $34.1 \%(n=30)$ & $100 \%(n=88)$ \\
\hline \multicolumn{2}{|c|}{ Total } & $60.5 \%(n=121)$ & $39.5 \%(\mathrm{n}=79)$ & $100 \%(n=200)$ \\
\hline
\end{tabular}

\subsection{Instruments Used}

Cyberbullying test: his instrument has been approved by Garaigordóbil [25], offering good adjustment and reliability indices. The instrument is composed of two scales, one of which collects information about bullying and the other cyber-bullying, both measured by means of a Likert-type scale with four response options, where $0=$ never and $3=$ always. Thereafter, a sum total is carried out that determines a total score for each role both for bullying as well as cyberbullying.

Bullying test: this scale allows us to determine the degree of bullying through 12 items grouped according to the role (observer, victim or aggressor) that assesses physical, verbal, social and psychological aggression in the three mentioned roles. The items were provided for the determination of the frequency of situations of bullying (e.g., Have you been abused or harassed in this way in the last year?). For bullying scale, an acceptable high internal consistency of $\alpha=0.802$ was obtained. The Kaiser-Meyer-Olkin (KMO) measure of sampling adequacy, the value of which was 0.79 for the tool's points, indicated that the data were adequate for conducting Exploratory Factor Analysis using Principal Component Analysis. The results indicate that the Bartlett test of sphericity proved to be significant $\left(\chi^{2}=11,634.93\right.$, g.l. $\left.=66 \mathrm{y}, p<0.001\right)$. To examine dimensionality, the varimax rotation method was used, which gave three factors for which the Total Variance Explained was $57.89 \%$, corresponding to the 4 points for the victim, 4 points for the aggressor and 4 points for the witness.

Cyberbullying test. This scale comprises 45 items grouped according to the roles connected to the situation of harassment (observer, victim or aggressor). The items determined the frequency of situations of cyberbullying, using Information and Communication Technologies (ICTs) (e.g., "Have you seen the sending of offensive and insulting messages via mobile phone or internet?"). For this scale, an excellent internal consistency was obtained; the value was $\alpha=0.925$. The Kaiser-Meyer-Olkin (KMO) measure of sampling adequacy, the value of which was 0.94 for the tool's points, indicated that the data were adequate for conducting Exploratory Factor Analysis using Principal Component Analysis. The results indicated that the Bartlett test of sphericity proved to be significant $\left(\chi^{2}=51,208.99\right.$, g.l. $=990 \mathrm{y}, p<0.001)$. To examine dimensionality, the varimax rotation method was used, which gave three factors for which the Total Variance Explained was $40.15 \%$, corresponding to the 15 points for the victim, 15 points for the aggressor and 15 points for the witness.

\subsection{Procedure}

The collaboration of the educational centers was requested through a meeting that was held between the Department of Didactics of Musical, Plastic and Corporal Expression of the University of Granada and the management board of several education centers. Topics were discussed about the nature and objectives of the study to be carried out. Subsequently, in those educational centers that decided to participate in the investigation, the informed consent of the legal tutors of the adolescents was requested through an authorization model signed by the parents or guardians of the minors. Regarding the application of the instruments in a pre-intervention and post-intervention manner, it should be noted that it was carried out during school hours in the selected centers without any type of incident occurring. Likewise, the researchers were present during the process, in order to ensure a 
correct application of the instruments. Note that the anonymity of all students was ensured, and they participated voluntarily and respected the agreement on research ethics of the Helsinki Declaration.

For the musical intervention, a meeting was held with the music teachers of the centers, who were handed over the general musical score of the piece to be played, La vida es Bella. The musical score was transcribed by researchers of the University of Granada, and teachers were instructed to teach it to the children over a period of four months. Teachers were asked to strive for a high standard in order to achieve an excellent musical performance. A good performance of music requires a social cohesion between all the members of the group because otherwise the musical results will not be attainable. With music, students learn to manage their emotions, improve standards of respect among participants, harmony and teamwork within a group. We wanted to get the students to join together to do their very best to achieve the objective of a good interpretation of their piece and, in turn, to learn to live together peacefully.

The teachers distributed the tasks among the students of the experimental groups of each center. ORFF instruments (xylophones, glockenspiels, metallophones, drums and non-pitched percussion instruments) and the recorder were used so as to make this intervention accessible to all secondary school children, regardless of their musical background, using instruments whose technique does not require any previous practice.

The rehearsal began, and the researchers of this project went to each school periodically to monitor progress and resolve any problems. After four months of preparation, the piece that was recorded by the research team was presented publicly.

During those months, one day was scheduled to conduct a talk in each center about human values. This talk was given by a member of the research team and lasted approximately an hour and a half. In the talk, the researcher got the children to open their hearts and minds, as there were several who openly talked about their experience, whether it was bullying, cyberbullying or both. The talk helped the children to understand the importance of human values in their lives.

\subsection{Data Analysis}

Statistical analysis was performed using the SPSS software ver. 24 (Armonk, NY, USA). The basic descriptions were analyzed using frequencies and averages, while the effect of the intervention program was checked through the $T$ test of related samples, checking the size of the effect through Cohen's $\mathrm{d}$. The normality of the data was performed using the Kolmogorov-Smirnov test, using the Lillieforts correction, and homoscedasticity through the Levene test. The internal reliability of the instruments used was assessed using the alpha of Cronbach coefficient, setting the reliability index at $95.5 \%$. Reliability was established at $\mathrm{p}<0.05$.

\section{Results}

The analysis performed on the effect of the intervention program on bullying and cyberbullying behaviors of "center A" is shown in Table 2. Significant differences $(p=0.044)$ were observed for the experimental group where bullying situations were witnessed, revealing a decrease in the average score $(2.269 \pm 2.215$ vs. $1.650 \pm 2.258)$ in the post-test measurement, with a low effect size $(d=-0.276)$. Significant differences were also revealed for cyberbullying situations linked to victimization, both for the experimental group $(\mathrm{p}=0.019 ; 1.650 \pm 2.913$ vs. $0.968 \pm 2.155)$ and for the control group $(\mathrm{p}=0.001$; $1.931 \pm 3.088$ vs. $0.775 \pm 1.717$ ). Specifically, a small effect size was shown for the experimental group $(\mathrm{d}=-0.266)$ and medium or moderate for the control group $(\mathrm{d}=-0.462)$. 
Table 2. Effect of the intervention program in education center A (La Salle).

\begin{tabular}{|c|c|c|c|c|c|c|c|c|c|}
\hline & & & $\mathbf{M}$ & SD & $\begin{array}{c}\text { CI } \\
\text { (L-U) }\end{array}$ & $t$ & Sig. & $d$ & r-size \\
\hline \multirow{2}{*}{ BV } & EG & $\begin{array}{l}\text { Pre-test } \\
\text { Post-test }\end{array}$ & $\begin{array}{l}0.952 \\
0.698\end{array}$ & $\begin{array}{l}1.650 \\
1.130\end{array}$ & $-0.107-0.615$ & 1.403 & 0.166 & -0.179 & -0.089 \\
\hline & CG & $\begin{array}{l}\text { Pre-test } \\
\text { Post-test }\end{array}$ & $\begin{array}{l}1.120 \\
0.948\end{array}$ & $\begin{array}{l}1.873 \\
1.419 \\
\end{array}$ & $-0.315-0.660$ & 0.708 & 0.482 & -0.103 & -0.051 \\
\hline \multirow{2}{*}{ BA } & EG & $\begin{array}{l}\text { Pre-test } \\
\text { Post-test }\end{array}$ & $\begin{array}{l}0.206 \\
0.190\end{array}$ & $\begin{array}{l}0.407 \\
0.470\end{array}$ & $-0.144-0.175$ & 0.198 & 0.843 & -0.036 & -0.018 \\
\hline & CG & $\begin{array}{l}\text { Pre-test } \\
\text { Post-test }\end{array}$ & $\begin{array}{l}0.482 \\
0.293\end{array}$ & $\begin{array}{l}1.202 \\
0.649\end{array}$ & $-0.082-0.461$ & 1.397 & 0.168 & -0.195 & -0.097 \\
\hline \multirow{2}{*}{ BW } & EG & $\begin{array}{l}\text { Pre-test } \\
\text { Post-test }\end{array}$ & $\begin{array}{l}2.269 \\
1.650\end{array}$ & $\begin{array}{l}2.215 \\
2.258\end{array}$ & $-0.043-1.281$ & 2.157 & $0.044^{*}$ & -0.276 & -0.137 \\
\hline & CG & $\begin{array}{l}\text { Pre-test } \\
\text { Post-test }\end{array}$ & $\begin{array}{l}2.403 \\
2.175\end{array}$ & $\begin{array}{l}2.448 \\
2.619\end{array}$ & $-0.519-0.975$ & 0.611 & 0.543 & -0.089 & -0.044 \\
\hline \multirow{2}{*}{ CBV } & EG & $\begin{array}{l}\text { Pre-test } \\
\text { Post-test }\end{array}$ & $\begin{array}{l}1.650 \\
0.968\end{array}$ & $\begin{array}{l}2.913 \\
2.155\end{array}$ & $0.116-1.248$ & 2.409 & 0.019 * & -0.266 & 0.131 \\
\hline & CG & $\begin{array}{l}\text { Pre-test } \\
\text { Post-test }\end{array}$ & $\begin{array}{l}1.931 \\
0.775\end{array}$ & $\begin{array}{l}3.088 \\
1.717\end{array}$ & $0.513-1.796$ & 3.604 & 0.001 * & -0.462 & -0.225 \\
\hline \multirow{2}{*}{ CBA } & EG & $\begin{array}{l}\text { Pre-test } \\
\text { Post-test }\end{array}$ & $\begin{array}{l}0.285 \\
0.079\end{array}$ & $\begin{array}{l}0.850 \\
0.517\end{array}$ & $0.003-0.409$ & 2.031 & $0.047^{*}$ & -0.292 & -0.144 \\
\hline & CG & $\begin{array}{l}\text { Pre-test } \\
\text { Post-test }\end{array}$ & $\begin{array}{l}0.965 \\
0.172\end{array}$ & $\begin{array}{l}4.460 \\
0.704\end{array}$ & $-0.294-1.880$ & 1.460 & 0.150 & -0.248 & -0.123 \\
\hline \multirow{2}{*}{ CBW } & EG & $\begin{array}{l}\text { Pre-test } \\
\text { Post-test }\end{array}$ & $\begin{array}{l}3.285 \\
1.381\end{array}$ & $\begin{array}{l}5.259 \\
2.439\end{array}$ & $0.733-3.076$ & 3.250 & $0.002 *$ & -0.464 & -0.226 \\
\hline & CG & $\begin{array}{l}\text { Pre-test } \\
\text { Post-test }\end{array}$ & $\begin{array}{l}4.087 \\
2.736\end{array}$ & $\begin{array}{l}7.344 \\
5.537\end{array}$ & $0.210-2.491$ & 2.372 & 0.021 * & -0.207 & -0.103 \\
\hline
\end{tabular}

Note 1: BV, Bullying-Victimization; BA, Bullying-Aggressiveness; BT, Bullying-Witness; CBV, Cyberbullying-Victimization; CBA, Cyberbullying-Aggressiveness, CBW, Cyberbullying-Witness. Note 2: EG, Experimental Group; CG, Control Group. Note 3: M, Median; SD, Standard Deviation, CI, Confidence Interval (Lower-Upper); $t, t$-test; $d$, Cohen's d. Note $4:{ }^{*}$, Statistically significant differences at level $p<0.05$.

Similarly, significant differences $(\mathrm{p}=0.047)$ were observed for the aggressiveness dimension linked to cyberbullying, specifically in the experimental group $(0.285 \pm 0.850$ vs. $0.079 \pm 0.517)$ with a low-moderate effect size $(\mathrm{d}=-0.292)$. There was also a reduction in the mean values of the situations where cyberbullying was witnessed, both in the experimental group $(p=0.002 ; 3.285 \pm 5.259$ vs. 1.381 \pm 2.439 ) and in the control group ( $p=0.021 ; 4.087 \pm 7.344$ vs. $2.736 \pm 5.537)$. Specifically, a larger effect size was revealed for the experimental group, being medium $(\mathrm{d}=-0.464)$ compared to the control value that was low $(\mathrm{d}=-0.207)$.

Table 3 shows the effect of the intervention program on bullying and cyberbullying behaviors in "center B". Significant differences $(p=0.001)$ were observed for the experimental group in the bullying situations in which victimization occurred, revealing a decrease in the average score (1.437 $\pm 1.785 \mathrm{vs}$. $0.500 \pm 0.945)$ in the post-test measurement, with a medium-high effect size $(d=-0.656)$. Significant differences were also revealed for cyberbullying situations involving witnesses, specifically for the experimental group ( $\mathrm{p}=0.049 ; 2.833 \pm 3.844$ vs. $1.770 \pm 3.832$ ). Specifically, a low effect size was verified $(\mathrm{d}=-0.276)$. 
Table 3. Effect of the intervention program in education center B (Enrique Nieto).

\begin{tabular}{|c|c|c|c|c|c|c|c|c|c|}
\hline & & & $\mathbf{M}$ & SD & $\begin{array}{c}\mathrm{CI} \\
\text { (L-U) }\end{array}$ & $t$ & Sig. & $d$ & r-size \\
\hline \multirow{2}{*}{ BV } & EG & $\begin{array}{l}\text { Pre-test } \\
\text { Post-test }\end{array}$ & $\begin{array}{l}1.437 \\
0.500\end{array}$ & $\begin{array}{l}1.785 \\
0.945\end{array}$ & $0.431-1.443$ & 3.726 & $0.001 *$ & -0.656 & -0.311 \\
\hline & CG & $\begin{array}{l}\text { Pre-test } \\
\text { Post-test }\end{array}$ & $\begin{array}{l}0.900 \\
1.200\end{array}$ & $\begin{array}{l}1.422 \\
1.669\end{array}$ & $-0.791-0.191$ & -1.248 & 0.222 & 0.193 & 0.096 \\
\hline \multirow{2}{*}{ BA } & EG & $\begin{array}{l}\text { Pre-test } \\
\text { Post-test }\end{array}$ & $\begin{array}{l}0.375 \\
0.250\end{array}$ & $\begin{array}{l}0.732 \\
0.956\end{array}$ & $-0.126-0.376$ & 1.000 & 0.322 & -0.146 & -0.073 \\
\hline & CG & $\begin{array}{l}\text { Pre-test } \\
\text { Post-test }\end{array}$ & $\begin{array}{l}0.333 \\
0.200\end{array}$ & $\begin{array}{l}0.802 \\
0.484\end{array}$ & $-0.216-0.483$ & 0.779 & 0.442 & -0.200 & -0.099 \\
\hline \multirow{2}{*}{ BW } & EG & $\begin{array}{l}\text { Pre-test } \\
\text { Post-test }\end{array}$ & $\begin{array}{l}2.125 \\
1.562\end{array}$ & $\begin{array}{l}2.614 \\
1.809\end{array}$ & $-0.168-1.293$ & 1.548 & 0.128 & -0.250 & -0.124 \\
\hline & CG & $\begin{array}{l}\text { Pre-test } \\
\text { Post-test }\end{array}$ & $\begin{array}{l}2.666 \\
2.100 \\
\end{array}$ & $\begin{array}{l}2.832 \\
2.482\end{array}$ & $-0.583-1.717$ & 1.007 & 0.322 & -0.212 & -0.105 \\
\hline \multirow{2}{*}{$\mathrm{CBV}$} & EG & $\begin{array}{l}\text { Pre-test } \\
\text { Post-test }\end{array}$ & $\begin{array}{l}1.229 \\
1.000\end{array}$ & $\begin{array}{l}2.434 \\
3.620\end{array}$ & $-0.307-0.765$ & 0.859 & 0.395 & -0.074 & -0.037 \\
\hline & CG & $\begin{array}{l}\text { Pre-test } \\
\text { Post-test }\end{array}$ & $\begin{array}{l}2.400 \\
2.000\end{array}$ & $\begin{array}{l}2.554 \\
2.573\end{array}$ & $-0.344-1.144$ & 1.099 & 0.281 & -0.156 & -0.077 \\
\hline \multirow{2}{*}{ CBA } & EG & $\begin{array}{l}\text { Pre-test } \\
\text { Post-test }\end{array}$ & $\begin{array}{l}0.270 \\
0.354\end{array}$ & $\begin{array}{l}1.332 \\
2.310\end{array}$ & $-0.393-0.226$ & -0.540 & 0.592 & 0.044 & 0.022 \\
\hline & CG & $\begin{array}{l}\text { Pre-test } \\
\text { Post-test }\end{array}$ & $\begin{array}{l}0.300 \\
0.266\end{array}$ & $\begin{array}{l}0.651 \\
0.980\end{array}$ & $-0.399-0.466$ & 0.158 & 0.876 & -0.040 & -0.020 \\
\hline \multirow{2}{*}{ CBW } & EG & $\begin{array}{l}\text { Pre-test } \\
\text { Post-test }\end{array}$ & $\begin{array}{l}2.833 \\
1.770\end{array}$ & $\begin{array}{l}3.844 \\
3.832\end{array}$ & $0.012-2.112$ & 2.035 & $0.047^{*}$ & -0.276 & -0.137 \\
\hline & CG & $\begin{array}{l}\text { Pre-test } \\
\text { Post-test }\end{array}$ & $\begin{array}{l}3.933 \\
2.600\end{array}$ & $\begin{array}{l}4.168 \\
3.838\end{array}$ & $-0.584-3.250$ & 1.422 & 0.166 & -0.332 & -0.164 \\
\hline
\end{tabular}

\section{Discussion}

In this study, we observed significant differences that lead us to deduce that in La Salle school, the intervention carried out produced effects in the experimental group, since fewer cases of bullying were observed. Ziv and Dolev said that relaxing background music in combination with other intervention actions can create a positive school environment and reduce aggressive behaviors [26]. However, although the number of victims and aggressors in La Salle has reduced since the intervention, the result is not significant. This means that in this semi-public education center, the intervention has produced only a slight decrease in bullying, and the intervention program has not produced the desired effect.

However, in the Enrique Nieto public education center, the victims of bullying in the experimental group have decreased considerably since the intervention. The intervention program has, therefore, clearly had a high impact. Likewise, the research carried out by Cook, Ogden and Winstone shows that music causes prosocial attitudes in the population that lead to a decrease in bullying victimization [27].

Comparing the La Salle education center with the Enrique Nieto one, it should be remembered that the latter was based on an average victimization value of almost double of that of La Salle; perhaps given that this was a center with more behavioral issues, the intervention program had more effect. We also believe that the sociocultural and identifying characteristics of each center have influenced this result. The Enrique Nieto school is a public education center with a very high number of students, a fact that prevents teachers from working on the students' individuality; this is unlike La Salle, where the teachers observe students at all times, thus limiting the number of conflicts.

In the case of cyberbullying, significant differences were observed between the pre- and post- tests at the La Salle education center, where victimization situations have decreased both in the experimental 
group and in the control group. As Uhlig, Jansen and Scherder say, music improves the levels of "psychological well-being, self-esteem and emotional regulation" of adolescents [28]. We need to bear in mind that both groups, the experimental and the control, belong to the same center, and the cases of cyberbullying do not only occur among students of the same group. Cyberbullying, due to the opportunities provided by new technologies, can be carried out on any student in any group. The intervention brought good results not just in the experimental group but also in the control group. We believe that this is the reason for the reduction in cyberbullying in both groups. In fact, the effect of the intervention has been much greater in the control group, where the number of victims was also previously higher.

However, although we found a decrease both in the experimental groups and in the control group, cyberbullying victimization situations at the Enrique Nieto school have not been significantly affected by the intervention program.

In the Enrique Nieto school, as in La Salle, bullying offenders do not want to identify themselves as such, and do not want to confess their actions for fear of reprisals, neither in the pre-test questionnaire nor in the post-test. However, our intervention has had low-moderate effects on cyberbullying aggressors in the experimental group of the semi-public school, having decreased the average aggressiveness score.

In the case of the witnesses of bullying, in the public school there were no significant differences between the pre-intervention test and the post-intervention test, despite the fact that victimization had greatly decreased. On the other hand, in the semi-public school, we saw a decrease in witnesses, without significantly reducing the victims. In the case of cyberbullying, in both school centers, there was a significant decrease in witnesses. This may be due to the fact that silence prevails more and more in the face of fear of reprisals from the aggressors. According to Garaigordóbil and Oñederra, the higher the educational level, the less frequently harassment is revealed to adults [29].

In the semi-public school center, as cyberbullying cases have decreased, cyberbullying witnesses have also decreased significantly, both in the experimental group and in the control. Although its effect was greater in the experimental group, the intervention has also brought benefits to the control. In the public center, cyberbullying witnesses have decreased in both groups, although more significantly in the experimental group.

The average score of the bullying and cyberbullying witnesses in both school centers, in both pre-test and post-test questionnaires, and in both groups (experimental and control) is striking due to their magnitude in relation to the average scores for victims and aggressors. That is, the students are happy to declare their observations; however, they are reluctant to declare themselves as victims and, above all, as aggressors. Fearing answers being traced to them, with shame and fear of answering honestly, they prefer to go unnoticed. Garaigordóbil reached the same conclusion in his study where he says that the number of witnesses is always higher than that of victims and aggressors [30].

However, we see that in the case of the La Salle school, the intervention program has been more effective for cyberbullying than for bullying. In cyberbullying, there has been a decrease in victims of harassment in both the experimental group and the control, in aggressors in the experimental group, and in witnesses of both groups. However, bullying has not presented a significant decrease. One reason for this may be the number of witnesses who declined to answer in the experimental group. In the public center, we found a considerable decrease in bullying victims, but not in cyberbullying victims; the opposite occurs with witnesses. Ortega-Ruiz, Del Rey and Casas [31] and Smith et al. [32] showed that there are great similarities between bullying and cyberbullying, and that bullying influences cyberbullying; frequently, when a victim is harassed in person, he is harassed at the same time online.

Likewise, we saw that after the intervention, there were more victims and witnesses of bullying in the semi-public center than in the public center (bullying victimization: 0.698 La Salle vs. 0.500 Enrique Nieto; bullying witness: 1.650 La Salle vs. 1.562 Enrique Nieto). The same thing happened in the control groups for the roles of bullying aggressor (0.293 La Salle vs. 0.200 Enrique Nieto), bullying witness (2.175 La Salle vs. 2.100 Enrique Nieto) and cyberbullying witness (2.736 La Salle vs. 2.600 Enrique Nieto). In fact, the public center started with harassment data significantly higher than those 
of the semi-public center, and quite similar for witnesses; and after the intervention they declined more than in the semi-public center.

We have come across limitations in this investigation. On the one hand, there is a discrepancy between the results; we see that in the case of bullying in the semi-public school, although neither victimization nor aggression decreased, the number of witnesses significantly decreased. In the case of the public school, the victims of bullying decreased but the witnesses did not decrease; in the case of cyberbullying, neither victims nor aggressors decreased, but witnesses did. These results are proof that students who have participated in this investigation are afraid of reprisals from their peers and are ashamed to talk about certain situations, especially those that are carried out face to face. Likewise, the aggressors do not declare themselves as such for fear of reprisals by adults. All this prevents them from giving clear and honest answers.

Although students were guaranteed anonymity throughout the entire investigation process, they still did not feel free to answer. This is a very important limitation of this work. We believe that the questionnaires must be completed by students in more private and confidential circumstances than those used. We should not conduct them in classrooms, which are some of the main places where harassment occurs, but in smaller units, such as offices, and in smaller groups, in a more relaxed and positive environment, that gives them confidence and allows them to concentrate and respond with honesty.

In addition, the intervention program was carried out in only two schools, one public and the other semi-public. Although the sample of students was significant, we also think that the sample size was a limitation. We consider it necessary now to conduct interventions in a larger number of schools. The different nature of the centers would allow us to discern between the advantages and disadvantages of this intervention and organize the experimental and control groups independently among themselves. In addition, we need centers in different areas, regions and countries where we can observe the advantages of the program according to the nature of the local people.

\section{Conclusions}

Based on the idea that music is a resource that can bring people closer together and improve levels of peace and coexistence, we have tried to do our bit to change society in the education sector in two schools in Melilla, by improving interactions between students and reducing cases of harassment and aggressive violence.

Once the intervention was finished, we obtained favorable results relating to the decrease in the levels of bullying and cyberbullying in the two centers. In the semi-public center, the intervention was more successful in cyberbullying, although bullying levels have also decreased. In the public center, bullying victimization levels have come down considerably. In addition, we have shown that students are able to perform to a satisfactory standard the song La vida es Bella, as a choir, with a school orchestra of ORFF instruments and recorders.

We consider that the $\mathrm{O} 1$ and $\mathrm{O} 2$ objectives set for this study have been met, since we have described the levels of violent behavior in the two centers involved and analyzed the effect of the intervention performed. However, although we have detailed the aggressive behaviors of these two school centers before and after the intervention, we believe that it is necessary to expand the sample size in order to define a model on aggressive behaviors.

However, the hypotheses raised have not been fully demonstrated. The H1 hypothesis has been fulfilled only in respect of some roles of bullying and cyberbullying but not in others. The public school center had lower rates of bullying than the semi-public school after the intervention, with regard to the roles of bullying victimization and bullying witnesses. In the other roles, however, the rates of bullying were higher, and the hypothesis was met. Taking into account the control groups, we could say that the public center has higher levels of bullying than the semi-public one, with regard to bullying victimization, cyberbullying victimization and cyberbullying aggressors. The $\mathrm{H} 2$ hypothesis is not proven either, because the students of the control groups have been favored by the intervention carried 
out in the experimental groups in relation to the decrease in cases of bullying. We can say that the levels of aggressive behavior in the experimental and control groups of both centers have decreased, with some roles showing a significant reduction. At La Salle school, the intervention has had a great effect on cyberbullying but not on bullying, and in the public center the victims of bullying decreased, but not in cyberbullying, contrary to what happens with witnesses.

Thus, it is impossible to say that our hypotheses have been fully fulfilled. We cannot say that we have found significant differences between public and semi-public centers in terms of decreasing number of violent cases. Nor can we state that the experimental groups have better results than the control groups, because the two groups belong to the same center and the aggressiveness is shown to people of both groups. The decrease in aggressors of the experimental group exerts a positive influence on the participants of the control group. Also, we cannot say that when bullying decreases, cyberbullying also decreases, since we have found confusing differences in both forms of harassment.

What we can state with certainty is that we have lowered the levels of aggressiveness in some bullying and cyberbullying roles in both centers. This leads us to believe that music is a resource that influences people's emotions, and that reduces levels of aggression. The application of programs that focus on social-emotional learning with music as the preferent element increases skills as interpersonal relationships and handle conflicts [20]. It is essential for the student to learn to constantly adapt their musical communication skills and friendship skills, which generates positive emotions within the group.

It is necessary to change the environment in which questionnaires are carried out and increase the number of centers in the sample, so that the experimental and control groups do not belong to the same school and there is a broader range of actions. In this way we would obtain more conclusive results.

It is necessary to develop a theoretical framework of music therapy to work with aggressors and victims of bullying and cyberbullying, always taking into account that music reinforced with talks about human values, provides the necessary conditions for reducing levels of aggression among people.

In the future we will carry out similar research at other centers in various cities with a larger sample size, throughout Spain, where we hope to overcome the limitations of this research and collect data to confirm that music is a valid resource for eradicating bullying and cyber-bullying in the not too distant future. To do this, we will try to apply social learning to our research and combine it with music to obtain greater differences in the experimental group.

Author Contributions: conceptualization: A.E.-L., J.A.O.R. and L.I.E.-V.; methodology: L.I.E.-V.; software: A.E.-L. and L.I.E.-V. validation: A.E.-L. and L.I.E.-V.; formal analysis: L.I.E.-V.; investigation: A.E.-L., J.A.O.R. and L.I.E.-V.; resources: A.E.-L., J.A.O.R. and L.I.E.-V.; data curation: A.E.-L. and L.I.E.-V.; writing-original draft preparation: A.E.-L.; writing-review and editing: A.E.-L., J.A.O.R. and L.I.E.-V.; visualization: A.E.-L., J.A.O.R. and L.I.E.-V.; supervision: A.E.-L.; project administration: A.E.-L. All authors have read and agreed to the published version of the manuscript.

Funding: This research received no external funding.

Acknowledgments: This study forms part of the research project titled "Pilot Study for evaluating and improving peer relationships at Primary and Secondary education centers of Melilla by way of Music" authorized by the Provincial Directorate for Education of the Autonomous City of Melilla. Many thanks to the "Enrique Nieto" High School and the "La Salle" School, both situated within the autonomous city of Melilla, for their collaboration in relation to this study and also to the teachers of the foregoing education centers, Begoña Bustos, María Mizzi, Elisabeth Moreno and Antonio Padilla that have been involved with and collaborated with the field work.

Conflicts of Interest: The authors declare no conflicts of interest.

\section{References}

1. Garaigordóbil, M.; Oñederra, J.A. La violencia entre iguales. Revisión teórica y estrategias de intervención; Ediciones Pirámide: Madrid, Spain, 2010.

2. Carrascosa, L.; Buelga, S.; Cava, M.J.; Ortega, J. Violencia escolar entre iguales y ajuste psicosocial: diferencias en función de la frecuencia de la agresión y victimización. In Psicología y Educación: Presente y Futuro; Castejón Costa, J.L., Ed.; ACIPE: Alicante, Spain, 2016; pp. 1463-1471. 
3. Lucas Molina, B.; Pulido Valero, R.; Solbes Canales, I. Violencia entre iguales en Educación Primaria: el papel de los compañeros y su relación con el estatus sociométrico. Psicothema 2011, 23, 245-251. [PubMed]

4. Loredo Abdalá, A.; Perea Martínez, A.; López Navarrete, G.E. "Bullying”: acoso escolar. La violencia entre iguales. Problemática real en adolescentes. Acta Pediatr. Mex. 2008, 29, 210-214.

5. Nocito Muñoz, G. Investigaciones sobre el acoso escolar en España: implicaciones psicoeducativas. Rev. Española Orientac. Psicopedag. 2017, 28, 104-118. [CrossRef]

6. Sánchez, C.; Cerezo, F. Variables personales y sociales relacionadas con la dinámica del bullying en escolares de Educación Primaria. Rev. Electron. Investig. Psicoeduc. Psigopedag. 2010, 8, 1696-2095.

7. Waasdorp, T.E.; Bradshaw, C.P. The overlap between cyberbullying and traditional bullying. J. Adolesc. Health. 2015, 56, 483-488. [CrossRef] [PubMed]

8. Baldry, A.C.; Farrington, D.P.; Sorrentino, A. School Bullying and Cyberbullying Among Boys and Girls: Roles and Overlap. J. Aggress. Maltreat. Trauma 2017, 26, 937-951. [CrossRef]

9. Del Rey, R.; Elipe, P.; Ortega-Ruiz, R. Bullying and cyberbullying: Overlapping and predictive value of the co-occurrence. Psicothema 2012, 24, 608-613. [PubMed]

10. Pacheco-Salazar, B. Violencia escolar: la perspectiva de estudiantes y docentes. Rev. Electr. Inv. Educ. 2018, 20, 112-121. [CrossRef]

11. Epelde-Larrañaga, A.; Oñederra-Ramírez, J.A.; Chacón-Cuberos, R. Prevalence of Cyberbullying : Data from two education centres in Spain. Int. J. Humanit. Educ. 2019, 17, 73-85. [CrossRef]

12. Ostrov, J.M.; Kamper, K.E. Future directions for research on the development of relational and physical peer victimization. J. Clinic Child Adolesc. Psychol. 2015, 44, 509-519. [CrossRef]

13. Wu, L.; Zhang, D.; Su, Z.; Hu, T. Peer victimization among children and adolescents: A meta-analytic review of links to emotional maladjustment. Clin. Pediatr. 2015, 54, 941-955. [CrossRef]

14. Buelga, S.; Cava, M.J.; Musitu, G. Reputación social, ajuste psicosocial y victimización entre adolescentes en el contexto escolar. Anal Psicol. 2012, 28, 180-187.

15. Schäfer, M.; Korn, S.; Smith, P.K.; Hunter, S.C.; Mora-Merchán, J.A.; Singer, M.M.; Meulen, K. Lonely in the crowd: Recollections of bullying. Br. J. Dev. Psychol. 2004, 22, 379-394. [CrossRef]

16. Polo del Río, M.I.; León del Barco, B.; Fajardo Bullón, F.; Felipe Castaño, E.; Palacios García, V. Perfiles de personalidad en víctimas del acoso escolar. Rev. INFAD Psicol. Int. J. Develop. Educ. Psychol. 2014, 1, 409-416.

17. Anderson, M.; Kaufman, J.; Simon, T.R.; School-associated violent deaths in the United States. $1994-1999$. JAMA 2001, 286, 2695-2702. [CrossRef] [PubMed]

18. Garaigordóbil, M.; Oñederra, J.A. Inteligencia emocional en las víctimas de acoso escolar y en los agresores. Eur. J. Educ. Psichol. 2010, 3, 243-256. [CrossRef]

19. Inglés, C.J.; Torregosa, M.S.; García-Fernández, J.M.; Martínez-Monteagudo, M.C.; Estévez, E.; Delgado, B. Conducta agresiva e inteligencia emocional en la adolescencia. Eur. J. Educ. Psychol. 2014, 7, $29-41$. [CrossRef]

20. Shafer, K.S.; Silverman, M.J. Applying a social learning theoretical framework to music therapy as a prevention and intervention for bullies and victims of bullying. Arts Psychother. 2013, 40, 495-500. [CrossRef]

21. Aróstegui, J.L. El desarrollo creativo en Educación Musical. Del genio artístico al trabajo colaborativo. Educaçao 2012, 37, 31-44.

22. Espinosa, S. Aprender haciendo, hacer jugando, jugar creando. Creat. Soc. 2008, 13, 175-189.

23. Pérez Aldeguer, S. El ritmo: una herramienta para la integración social. Ensayos: Rev. Facul. Educ. Albacete 2008, 23, 189-198.

24. Merino-Marban, R.; Mayorga-Vega, D.; Fernandez-Rodríguez, E.; Estrada, F.; Viciana, J. Effect of a physical education-based stretching programme on sit-and-reach score and its posterior reduction in elementary school children. Eur. Phys. Educ. Rev. 2015, 21, 83-92. [CrossRef]

25. Garaigordóbil, M. Ficha técnica. Cyberbulling. Screaning de acoso entre iguales; TEA Ediciones: Madrid, Spain, 2013.

26. Ziv, N.; Dolev, E. The effect of background Music on bullying: A pilot study. Child. Sch. 2013, 35, 83-90. [CrossRef]

27. Cook, A.; Ogde, J.; Winstone, N. The impact of a school-based musical contact intervention on prosocial attitudes, emotions and behaviours: A pilot trial with autistic and neurotypical children. Autism 2019, 23, 933-942. [CrossRef] [PubMed] 
28. Uhlig, S.; Jansen, E.; Scherder, E. “Being a bully isn't very cool ... ": Rap \& Sing Music Therapy for enhancent school setting-a randomized controlled trial. Psychol. Music 2018, 46, 568-587. [CrossRef] [PubMed]

29. Garaigordóbil, M.; Oñederra, J.A. Acoso y violencia escolar en la Comunidad Autónoma del País Vasco. Psicothema 2009, 21, 83-89.

30. Garaigordóbil, M. Ciberbullying en adolescentes y jóvenes del País Vasco: Cambios con la edad. Anal. Psicol. 2015, 31, 1069-1076. [CrossRef]

31. Ortega Ruiz, R.; Del Rey, R.; Casas, J.A. Evaluar el bullying y el cyberbullying. Validación española del EBIP-Q y del ECIP-Q. Psicol. Educ. 2016, 22, 71-79. [CrossRef]

32. Smith, P.K.; Mahdavi, J.; Carvalho, M.F.; Fisher, S.; Russell, S.; Tippett, N. Cyberbullying: its nature and impact in secondary school pupils. J. Child Psichol. Psichiatr. 2008, 49, 376-385. [CrossRef]

(C) 2020 by the authors. Licensee MDPI, Basel, Switzerland. This article is an open access article distributed under the terms and conditions of the Creative Commons Attribution (CC BY) license (http://creativecommons.org/licenses/by/4.0/). 